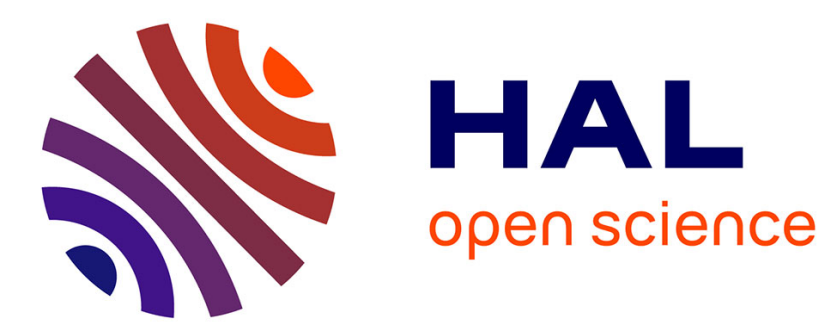

\title{
Element Case Studies: Cobalt
}

Michel-Pierre Faucon, Olivier Pourret, Bastien Lange

\section{To cite this version:}

Michel-Pierre Faucon, Olivier Pourret, Bastien Lange. Element Case Studies: Cobalt. Antony van der Ent; Alan J.M. Baker; Guillaume Echevarria; Marie-Odile Simonnot; Jean Louis Morel. Agromining: Farming for Metals: Extracting Unconventional Resources Using Plants, Springer, pp.385-391, 2021, Mineral Resource Reviews, 978-3-030-58903-5. 10.1007/978-3-030-58904-2_18 . hal-03066540

\section{HAL Id: hal-03066540 https://hal.science/hal-03066540}

Submitted on 15 Dec 2020

HAL is a multi-disciplinary open access archive for the deposit and dissemination of scientific research documents, whether they are published or not. The documents may come from teaching and research institutions in France or abroad, or from public or private research centers.
L'archive ouverte pluridisciplinaire HAL, est destinée au dépôt et à la diffusion de documents scientifiques de niveau recherche, publiés ou non, émanant des établissements d'enseignement et de recherche français ou étrangers, des laboratoires publics ou privés. 
archives-ouvertes

\section{Element Case Studies: Cobalt}

Michel-Pierre Faucon, Olivier Pourret, Bastien Lange

\section{To cite this version:}

Michel-Pierre Faucon, Olivier Pourret, Bastien Lange. Element Case Studies: Cobalt. Agromining: Farming for Metals: Extracting Unconventional Resources Using Plants, pp.385-391, 2021, 10.1007/978-3-030-58904-2_18. hal-03066540

\section{HAL Id: hal-03066540 \\ https://hal.archives-ouvertes.fr/hal-03066540}

Submitted on 15 Dec 2020

HAL is a multi-disciplinary open access archive for the deposit and dissemination of scientific research documents, whether they are published or not. The documents may come from teaching and research institutions in France or abroad, or from public or private research centers.
L'archive ouverte pluridisciplinaire HAL, est destinée au dépôt et à la diffusion de documents scientifiques de niveau recherche, publiés ou non, émanant des établissements d'enseignement et de recherche français ou étrangers, des laboratoires publics ou privés. 


\title{
Chapter 12.2 \\ Element case studies: Cobalt
}

\section{Michel-Pierre Faucon, Olivier Pourret and Bastien Lange}

\begin{abstract}
Cobalt is economically considered as a critical metal. The main known Co ore deposits are found in the Katanga Copperbelt (Democratic Republic of Congo) where a high richness of $\mathrm{Cu}-\mathrm{Co}$ tolerant and accumulator plants have developed. Cobalt mining has disseminated and disseminates large quantities of wastes in the environment and becomes a major environmental issue. Reduction of environmental risks and Co dispersion can be performed by phytoremediation and/or agromining, using trace element tolerant and putative hyperaccumulator plants originated from the biodiversity of natural $\mathrm{Co} / \mathrm{Cu}$-enriched habitats. Accumulation of foliar Co to $>300 \mu \mathrm{g} \mathrm{g}^{-1}$ is exceptionally rare globally, and known principally from the Copperbelt of Central Africa. This chapter highlights advances on Co accumulation in plants, examines the potential of a Co accumulator in agromining, and defines perspectives for Co agromining by designing multi-functions and services of agroecosystems by a functional plant traits approach.
\end{abstract}

M-P. Faucon $(\bowtie) \cdot$ O. Pourret $・$ B. Lange

AGHYLE, Institut Polytechnique UniLaSalle, Beauvais, France. Email: michelpierre.faucon@unilasalle.fr

\subsubsection{Introduction}


Cobalt (Co) is one of the elements defined as a critical metal over the next 5-15 years (Pourret and Faucon 2018). Demand for Co increased considerably after the Second World War, driven by the use of high-purity Co in jet engines and gas turbines. Cobalt demand and corresponding production have further accelerated in the past thirty years. Indeed, it reflects the increased use of $\mathrm{Co}$ as an essential constituent of materials used in high-technology industries including rechargeable Li batteries, superalloys and catalysts (Crundwell et al. 2011). The main known ore deposits are found in the Katangan Copperbelt (Democratic Republic of Congo) where $49.3 \%$ of the known world reserves are identified. The Katangan Copperbelt acts as the major producer of cobalt (Fig.1) accounting $64.3 \%$ of the world production in 2018 (USGS 2019). Minor resources of Co originate from lateritic nickel mines worldwide (Decrée et al. 2015). The average cobalt price ranges from 30,000 to $40000 \mathrm{US} \$ / \mathrm{t}$ in 2018-19 with a maximum trade value of >90,000 US\$/t early 2018 (London Metal Exchange values).

Moreover, over a century, mining has disseminated large quantities of wastes in the environment and become a major environmental issue (Pourret et al. 2016). As a consequence, these activities have created secondary metalliferous substrates with elevated concentrations of trace elements including Co (more than 1000 times greater than the concentration in normal soil) (Faucon et al. 2011, 2012). Such exploitation results in huge occupation of soil (over $30000 \mathrm{~km}^{2}$ ) and implies soil degradation (Dupin et al. 2013). In southeastern Central Africa, trace elements contamination constitutes a major environmental issue related to low $\mathrm{pH}$ of Ferralsol increasing trace elements mobility, intense erosion by rainfall in the rainy season, and aerial dispersal of metal particles by wind in the dry season (Pourret et al. 2016). Besides, Co is highly toxic and directly impacts human heath, given as there is an elevated cobalt exposure in the general population of southern D.R. Congo (Banza et al. 2009, Cheyns et al. 2014, Squadrone et al. 2016).

Reduction of environmental risks and Co dispersion can be performed by phytoremediation and agromining, using trace elements tolerant and putative hyperaccumulator plants from the plant biodiversity of natural habitats enriched in $\mathrm{Cu}$ and $\mathrm{Co}$ (Ilunga et al. 2015; Boisson et al. 2015; Faucon et al. 2016). Agromining is an alternative treatment for contaminated soils, and an application of phytotechnologies to exploit secondary resources. Agromining was studied at field scale (Chaney et al. 2007; van der Ent et al. 2015; Bani et al. 2015), but is limited to Ni. Cobalt agromining may, therefore, be considered for Co-contaminated lands because 30 putative Co hyperaccumulator plants were highlighted in southeastern of DR Congo (Brooks et al. 1980; Reeves and Baker 2000; Faucon et al. 2007) and of the possible attainable yields and the high metal product value.

Cobalt accumulators present a high variation of foliar Co concentration that can be explained by genetic variation and chemical soil factors involved in Co availability (Lange et al 2017). Besides, Co accumulators present high functional diversity (i.e. in life cycles, lateral spreading capacity, type and depth of underground system, growth phenology, N symbiotic fixation, etc.) (Ilunga et al. 2015) that has an influence on ecosystem processes such as 
biomass productivity, Co mobility and transfer, etc. (Faucon 2015). Cobalt agromining should consider intra and interspecific variation of leaf Co accumulation and functional plant diversity to design multi-functional and services of these new cropping systems.

In this chapter, we focus on putative Co hyperaccumulator plants and their implication in Co agromining. We review recent advances on Co accumulation, examine the potential of a Co accumulator in agromining and define perspectives for Co agromining by designing multifunctions and services of agroecosystem using a functional plant traits approach.

\subsubsection{Variation in cobalt accumulation}

Cobalt tolerant populations have been reported in the literature in several dozen species collected from nature (i.e. from $\mathrm{Cu}$ and $\mathrm{Co}$ steppic savanna), but the capacity to grow under elevated Co concentrations without toxicity symptoms or growth inhibition has less been demonstrated experimentally (Lange et al. 2017). Cobalt accumulation variation has been demonstrated between three closely related Silene taxa (Baker et al. 1983). Cobalt accumulation exists in Anisopappus chinensis (Asteraceae) as foliar Co concentration increases in relation to Co soil concentration without a decrease of biomass or toxicity symptoms (Lange 2016).

High inter and intraspecific variation of Co accumulation exists (Faucon et al. 2007, 2009, Lange et al. 2014). This high phenotypic variation of Co accumulation can be explained by variation Co total concentration in soil and chemical soil factors influencing Co mobility and availability (Faucon et al. 2009). The $\mathrm{Cu}$-Co outcrops have high total soil Co concentrations (up to $3451 \mu \mathrm{g} \mathrm{g}^{-1}$ ) from which a fraction is mobile (39-2146 $\mu \mathrm{g} \mathrm{g}^{-1}$ ) (Pourret et al. 2016). This permits high Co accumulation by A. chinensis (up to $2822 \mu \mathrm{g} \mathrm{g}^{-1}$ foliar Co). Overall, the strong affinity of Mn oxides for Co may explain the lower Co mobility in Mn-rich soils (Collins and Kinsela 2011, Lange et al. 2014). Cobalt accumulation (in Crepidorhopalon perennis (Linderniaceae) and A. chinensis) was strongly influenced by free Co and by Co adsorbed onto the OM and Fe oxide fractions (Lange et al. 2014).

The most tolerant taxon of Silene was the less accumulating for a given soil Co concentration. The intra-specific variation of Co accumulation by metallophytes from natural Co-enriched soils has not yet been tested. For the facultative metallophyte Anisopappus chinensis, the strong variation in the degree of Co tolerance between populations suggests intra-specific variation of accumulation (Lange 2016).

\subsection{Potential of cobalt agromining}

Cobalt agromining was proposed in last decade as a possibility using Ni-hyperaccumulator species on ultramafic soils (Homer et al. 1991). However, Ni limits the uptake of Co in most Ni-hyperaccumulator plants (Malik et al. 2000) and so negatively influences the performance of Co agromining. Best candidate species for Co agromining are plants with elevated 
extracting yields (i.e. biomass $\mathrm{x}$ Co shoot concentration) and plants that are both tolerant to $\mathrm{Cu}$ and $\mathrm{Co}$ given as most $\mathrm{Co}$ tolerant plants grow in $\mathrm{Cu}-\mathrm{Co}$ rich soils in southeastern of $\mathrm{D}$. R. Congo.

Lange (2016) evaluated Co agromining potential using metallicolous populations of $A$. chinensis from Co-enriched soils presenting elevated leaf Co concentrations in nature $\left(30-2822 \mu \mathrm{g} \mathrm{g}^{-1}\right)$. Mean of shoot biomass of individuals of A. chinensis $(\mathrm{n}=20)$ was $0.8 \mathrm{~g}$ (range: $0.14-3.79 \mathrm{~g}$ ). Biomass productivity (Ybio) was estimated to $16 \mathrm{~g} / \mathrm{m}^{2} /$ year whether $160 \mathrm{~kg} / \mathrm{ha} /$ year (range: $20-320 \mathrm{~kg} / \mathrm{ha} /$ year). Total Co phytoextracted (YCo $=$ FCo. Ybio) /ha/year from a contaminated soil using plants of $A$. chinensis from "Fungurume V" was 176 $\mathrm{g} /$ ha/year (max: $864 \mathrm{~g} \mathrm{ha}^{-1}$ ) (Lange 2016). Due to the great variability of its ability to extract Co from the soil, agromining using A. chinensis should be improved by plant selection and genotyping (Chaney et al. 2007). Potentially, Co agromining could be improved by performing a multispecies system introducing other Co tolerant and accumulator species. Legume species such as Crotalaria cornetii (Fabaceae) which grows in natural and secondary metalliferous habitats (Leteinturier et al. 2002) can improve facilitation process and increase biomass productivity and potentially YCo. Such an innovative system on Co contaminated soils could lead to an increased phytoextraction yield as some species are known to accumulate $\mathrm{Co}$ in their shoots more effectively than A. chinensis, such as Haumaniastrum robertii (Lamiaceae, Co leaf concentration : $4000 \mathrm{mg} \mathrm{kg}^{-1}$ ) (Morrison et al. 1981). This first evaluation on phytoextraction of soils contaminated by Co in Tropical Africa has shown limited achievable yields of Co phytoextracted. Perspectives would be to test it at field scale with a multi-species system, introducing functional diversity of Co-accumulator plants (species and populations) (Figure 2).

\subsubsection{Functional plant diversity of cobalt agromining systems}

In the last decade, considerable progress in ecology has been achieved due to the elaboration of the concept of functional traits. Functional traits are defined as "morpho-physiophenological traits which impact fitness indirectly via their effects on growth, reproduction and survival" (Violle et al. 2007). Relationships between traits associated with the response of organisms to environmental factors such as resources and disturbances (response traits), and traits that determine effects of organisms on ecosystem functions (effect traits), are recently studied in few processes and ecosystem services (Garnier et al. 2016).

Phytoremediation and agromining generally attempt to study effects of species or species mixtures on ecological processes to restore and design ecosystems independently of a functional trait approach (Faucon 2015). Agromining based on taxonomical description does not allow quantifying effect of plant species on ecosystem processes and services. Challenge is to link recent literature on below and aboveground functional traits of plant and ecosystem processes such as trace element mobility, water transfer and sediment transport, to improve ecological engineering and associated services, especially agromining yield, landscape 
restoration, reduction of trace element transfer and water contamination, carbon sequestration, etc.

From 30 putative Co accumulators that present high variability of morphology, life cycle and physiology (Ilunga et al. 2015; Malaisse et al. 2016), several traits could be selected to develop multifunctional Co agromining system.

\subsection{Plant functional diversity to improve Co agromining}

In Co accumulators, functional divergence of root traits should be considered to improve biomass productivity and yield of Co agromining. Effectively, the intercropping with functional diversity of crop species corresponds to temporal and spatial niche differentiation in resource acquisition for these species, associated with an increase in productivity compared to a monoculture (Li et al. 2014; Faucon et al. 2015). Spatial niche differentiation associated with root morphology and the capability to exploit nutrient in soils can also explain the way in which species colonize the soil profile and the total soil volume occupied by the crop (Lynch 2011). Physiological root traits should also be considered to improve Co agromining yield, especially root-induced processes such as proton and/or carboxylate releasing which would directly affect Co availability in rhizosphere (Lange et al. 2017). In contrary to functional diversity (FD) of root traits, FD of leaf traits and plant height can present a negative effect on biomass productivity explaining by an increased light competition.

\subsection{Plant functional traits involved in landscape restoration, and Co transfer}

Traits of perennial cycle, high lateral spreading capacity and growth phenology at the dry season, will be prioritized to develop a dense cover to restore landscape, reduce runoff and soil erosion and thus, Co transfer (Egoh et al. 2011). Functional diversity (FD) should be considered to improve these ecosystem services, such as FD of deep underground system, to improve root density and thus soil cohesion and stability (Gyssels et al. 2005), of growth phenology (both dry and rainy seasons) (Ilunga et al. 2015).

\subsection{Conclusions}

The application of Co accumulator plants in agromining is limited because their accumulation characteristics mean that only in soils with high concentration of available Co plants may yield sufficient accumulation in the shoots to develop this technology. Cobalt agromining may be considered for strongly Co-contaminated soils and tailings, because Co is economically considered a critical metal (Gunn 2014). Perspectives are to understand relationships between plant functional traits and ecosystem processes/services, to design multi-functional and multi-services agromining systems. 


\section{References}

Baker AJM, Brooks RR, Pease AJ, Malaisse F (1983) Studies on copper and cobalt tolerance in three closely related taxa within the genus Silene L. (Caryophyllaceae) from Zaïre. Plant Soil 73:377-385

Banza CLN, Nawrot TS, Haufroid V, Decrée S, De Putter T, Smolders E, Kabyla BI, Luboya ON, Ilunga AN, Mutombo AM, Nemery B (2009) High human exposure to cobalt and other metals in Katanga, a mining area of the Democratic Republic of Congo. Environ Res 109:745-752

Bani A, Echevarria G, Sulçe S, Morel JL (2015) Improving the agronomy of Alyssum murale for extensive phytomining: a five-year field study. Int J Phytoremediation 17:117-127

Boisson S, Le Stradic S, Collignon J, Séleck M, Malaisse F, Shutcha MN, Faucon MP, Mahy G (2015) Potential of copper-tolerant grasses to implement phytostabilisation strategies on polluted soils in South DR Congo. Environ. Sci Pollut Res 1-13

Brooks RR, Reeves RD, Morrison RS, Malaisse F (1980) Hyperaccumulation of copper and cobalt - A review. Bull Soc Roy Bot Belg 113:166-172

Chaney RL, Angle JS, Broadhurst CL, Peters CA, Tappero RV, Sparks DL (2007) Improved understanding of hyperaccumulation yields commercial phytoextraction and phytomining technologies. J Environ Qual 36:1429-1443

Cheyns K, Banza Lubaba Nkulu C, Ngombe LK, Asosa JN, Haufroid V, De Putter T, Nawrot T, Kimpanga CM, Numbi OL, Ilunga BK, Nemery B, Smolders E (2014) Pathways of human exposure to cobalt in Katanga, a mining area of the D.R. Congo. Sci Total Environ 490:313321

Collins RN, Kinsela AS (2011) Pedogenic factors and measurements of the plant uptake of cobalt. Plant Soil 339:499-512

Crundwell FK, Moats MS, Ramachandran V, Robinson TG, Davenport WG (2011)

Extractive Metallurgy of Nickel, Cobalt and Platinum Group Metals. Elsevier, Oxford.

Decrée S, Pourret O, Baele J-M (2015) Rare earth element fractionation in heterogenite $(\mathrm{CoOOH})$ : implication for cobalt oxidized ore in the Katanga Copperbelt (Democratic Republic of Congo). J Geochem Explor159:290-301.

Dupin L, Nkono C, Burlet C, Muhashi F, Vanbrabant Y (2013) Land cover fragmentation using multi-temporal remote sensing on major mine sites in Southern Katanga (Democratic Republic of Congo). Advances in Remote Sensing 2:127-139 
Egoh BN, Reyers B, Rouget M, Richardson DM (2011) Identifying priority areas for ecosystem service management in South African grasslands. J. Environ. Manag. 92: 16421650

Faucon MP, Shutcha MN, Meerts P (2007) Revisiting copper and cobalt concentrations in supposed hyperaccumulators from SC Africa: influence of washing and metal concentrations in soil. Plant Soil 301: 29-36

Faucon M-P, Colinet G, Mahy G, Luhembwe MN, Verbruggen N, Meerts P (2009) Soil influence on $\mathrm{Cu}$ and $\mathrm{Co}$ uptake and plant size in the cuprophytes Crepidorhopalon perennis and C. tenuis (Scrophulariaceae) in SC Africa. Plant Soil 317:201-212

Faucon M-P, Parmentier I, Colinet G, Mahy G, Ngongo Luhembwe M, Meerts P (2011) May rare metallophytes benefit from disturbed soils following mining activity? The case of the Crepidorhopalon tenuis in Katanga (D. R. Congo). Restor Ecol 19:333-343

Faucon M-P, Tshilong BM, Van Rossum F, Meerts P, Decocq G, Mahy G (2012) Ecology and Hybridization Potential of Two Sympatric Metallophytes, the Narrow Endemic Crepidorhopalon perennis (Linderniaceae) and its More Widespread Congener C. tenuis. Biotropica 44:454-462

Faucon M-P (2015) Ecologie et biogéochimie des interactions sol-plante et leurs implications en conservation de la biodiversité, ingénierie écologique et agroécologie, HDR dissertation, Université de Picardie, UniLaSalle, 106 pp.

Faucon M-P, Houben D, Reynoird J-P, Dulaurent-Mercadal AM, Armand R, Lambers H (2015) Advances and perspectives to improve the phosphorus availability in cropping systems for agroecological phosphorus management. Adv Agron 134:51-79

Faucon M-P, Le Stradic S, Boisson S, wa Ilunga EI, Séleck M, Lange B, Guillaume D, Shutcha MN, Pourret O, Meerts P, Mahy G (2016) Implication of plant-soil relationships for conservation and restoration of copper-cobalt ecosystems. Plant Soil 403:153-165

Garnier E, Navas ML, Grigulis K (2016) Plant functional diversity: organism traits, community structure, and ecosystem properties. Oxford University Press, 256 pp.

Gunn G (2014) Critical metals handbook. John Wiley \& Sons, pp. 454.

Gyssels G, Poesen J, Bochet E, Li Y (2005) Impact of plant roots on the resistance of soils to erosion by water: a review. Prog Phys Geogr 29:189-217 
Homer FA, Morrison RS, Brooks RR, Clemens J, Reeves RD (1991) Comparative studies of nickel, cobalt, and copper uptake by some nickel hyperaccumulators of the genus Alyssum. Plant Soil 138: 195-205

Ilunga wa Ilunga E, Mahy G, Piqueray J, Séleck M, Shutcha MN, Meerts P, Faucon M-P (2015) Plant functional traits as a promising tool for the ecological restoration of degraded tropical metal-rich habitats and revegetation of metal-rich bare soils: A case study in copper vegetation of Katanga, DRC. Ecol. Eng. 82:214-221

Lange B, Faucon MP, Meerts P, Shutcha M, Mahy G, Pourret O (2014) Prediction of the edaphic factors influence upon the copper and cobalt accumulation in two metallophytes using copper and cobalt speciation in soils. Plant Soil 379: 275-287

Lange B (2016) Tolérance et accumulation du cuivre et du cobalt - Implication pour la phytoremédiation des sols contaminés. Thèse de doctorat, Université Libre de Bruxelles, Université Picardie Jules Verne, 160 pp.

Lange B, van der Ent A, Baker AJM, Echevarria G, Mahy G, Malaisse F, Meerts P, Pourret O, Verbruggen N, Faucon MP. (2017) Copper and cobalt accumulation in plants: a critical assessment of the current status of knowledge. New Phytol 213 : 537-551

Leteinturier B (2002) Evaluation du potentiel phytocénotique des gisements cuprifères d'Afrique centro-australe en vue de la phytoremédiation de sites pollués par l'activité minière. PhD. Thesis, Faculté des Sciences agronomiques de Gembloux, Belgium, 361 pp.

Li L, Tilman D, Lambers H, Zhang FS (2014) Plant diversity and overyielding: insights from belowground facilitation of intercropping in agriculture. New Phytol 203:63-69

Lynch J-P (2011) Root phenes for enhanced soil exploration and phosphorus acquisition: tools for future crops. Plant physiol156:1041-1049

Malaisse F, Schaijes M, D'Outreligne C (2016) Copper-cobalt flora of Upper Katanga and Copperbelt. Field guide. Over 400 plants, 1,000 photographs and 500 drawings. Presses agronomiques de Gembloux, 422 pp.

Malik M, Chaney RL, Brewer EP, Li YM, Angle JS (2000) Phytoextraction of soil cobalt using hyperaccumulator plants. Int J Phytoremediation 2:319-329

Morrison RS, Brooks RR, Reeves RD, Malaisse F, Horowitz P, Aronson M, Merriam GR. 1981. The diverse chemical forms of heavy metals in tissue extracts of some metallophytes from Shaba province, Zaïre. Phytochemistry 20:455-458 
Pourret O, Lange B, Bonhoure J, Colinet G, Decrée S, Mahy G, Séleck M, Shutcha M. and Faucon M-P (2016) Assessment of soil metal distribution and environmental impact of mining in Katanga (Democratic Republic of Congo). Appl Geochem 64:43-55

Pourret O, Faucon M-P (2018) Cobalt. In: White, W.M. (Ed.), Encyclopedia of Geochemistry: A Comprehensive Reference Source on the Chemistry of the Earth. Springer International Publishing, Cham, pp. 291-294.

Reeves RD, Baker AJM (2000) Metal-accumulating plants. In: Raskin I, Ensley BD (eds) Phytoremediation of toxic metals. Wiley, New York, pp 193-221

Squadrone S, Burioli E, Monaco G, Koya MK, Prearo M, Gennero S, Dominici A, Abete MC (2016) Human exposure to metals due to consumption of fish from an artificial lake basin close to an active mining area in Katanga (DR Congo). Sci Total Environ 568:679-684

USGS, 2019. Mineral Commodity Summaries 2018

van der Ent A, Baker AJM, Reeves RD, Chaney RL, Anderson CWN, Meech JA, Erskine PD, Simonnot M-O, Vaughan J, Morel JL, Echevarria G, Fogliani B, Rongliang Q, Mulligan DR (2015) Agromining: Farming for Metals in the Future? Environ Sci Technol 49:47734780 


\section{FIGURE CAPTIONS}

Figure 1. Production of cobalt (data collected from mineral commodity summaries yearly published by USGS).

Figure 2. A few putative Co accumulator plants. A: Anisopappus chinensis Hook.f. \& Arn. (Asteraceae) (C) Lange B, B: Haumaniastrum robertii (Robyns) P.A. Duvign. \& Plancke (Lamiaceae) (c) Faucon M-P, C: Crepidorhopalon perennis (P.A. Duvign.) Eb. Fisch. (Linderniaceae) (C) Faucon M-P, D: Buchnera henriquesii Engl. (Orobanchaceae) () Séleck M, E: Acalypha cupricola Robyns (Euphorbiaceae) (C) Lebrun J., F: Triumfetta welwitschii Mast. (Malvaceae) () Séleck M. 


\section{FIGURE 1}

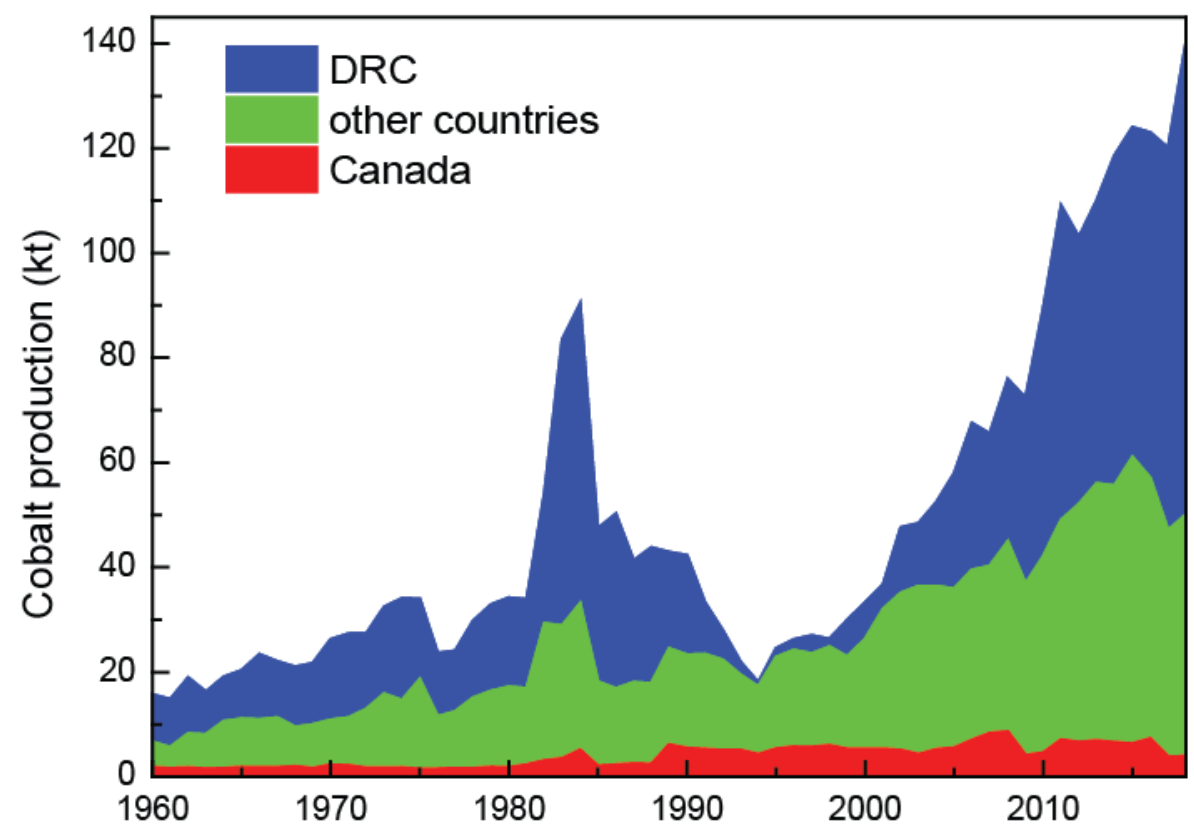




\section{FIGURE 2}
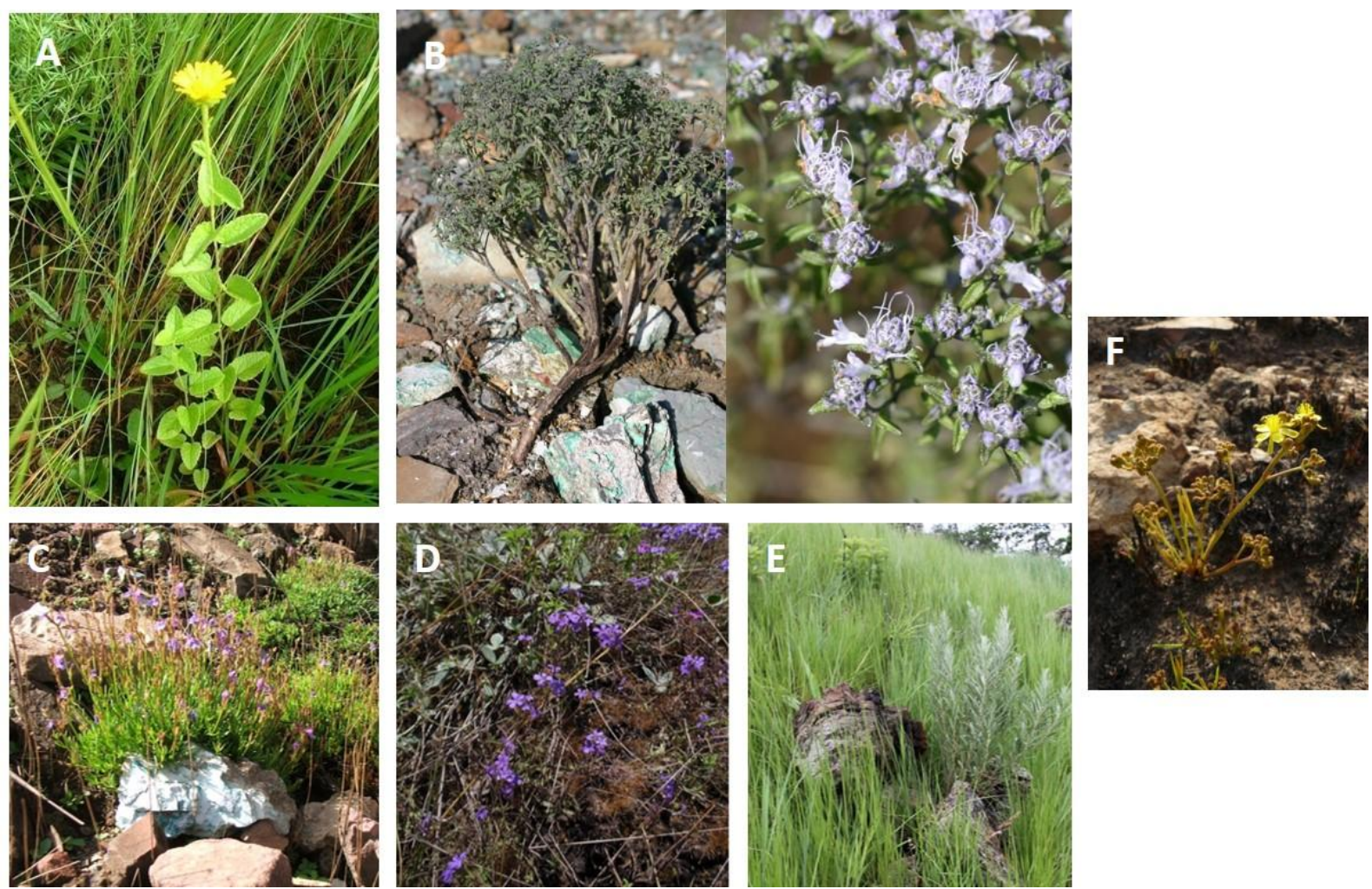